\title{
Leucaena toxicity: a new perspective on the most widely used forage tree legume
}

\author{
MICHAEL J. HALLIDAY ${ }^{1}$, JAGADISH PADMANABHA ${ }^{2}$, CHRIS S. MCSWEENEY ${ }^{2}$, GRAHAM KERVEN ${ }^{1}$ AND \\ H. MAX SHELTON ${ }^{1}$
}

${ }^{I}$ School of Agriculture and Food Sciences, The University of Queensland, St Lucia, Qld, Australia. www.uq.edu.au/agriculture/

${ }^{2}$ CSIRO Animal, Food \& Health Sciences, Queensland Biosciences Precinct, St Lucia, Qld, Australia. www.csiro.au/Organisation-Structure/Divisions/Livestock-Industries

Keywords: Leucaena leucocephala, Synergistes jonesii, mimosine, dihydroxypyridine, DHP, urine.

\begin{abstract}
The tree legume Leucaena leucocephala (leucaena) is a high quality ruminant feed, vitally important for livestock production in the tropics, despite the presence of mimosine in the leaves. This toxic non-protein amino acid has the potential to limit productivity and adversely affect the health of animals. In the 1980s, the ruminal bacterium Synergistes jonesii was discovered and subsequently distributed in Australia as an oral inoculum to overcome these toxic effects. However, in recent times, a number of factors, including: surveys of the status of toxicity worldwide; improved understanding of the chemistry and mode of action of the toxins; new techniques for molecular sequencing; and concerns about the efficacy of the in vitro inoculum; have cast doubt on some past understanding of leucaena toxicity and provide new insights into the geographical spread of $S$. jonesii. There is also confusion and ignorance regarding the occurrence and significance of toxicity in many countries worldwide. Ongoing research into the taxonomy and ecology of the Synergistetes phylum, improved methods of inoculation, and improved management solutions, along with awareness-raising extension activities, are vital for the future success of leucaena feeding systems.
\end{abstract}

\section{Resumen}

La leguminosa arbórea Leucaena leucocephala, conocida comúnmente como leucaena, es un alimento para rumiantes de alta calidad y de vital importancia para la producción pecuaria en el trópico, a pesar de la presencia de mimosina en sus hojas. Este tóxico aminoácido no proteico tiene el potencial de limitar la productividad y afectar negativamente la salud de los animales. En la década de 1980, se descubrió la bacteria ruminal Synergistes jonesii, la cual fue luego distribuida en Australia como inóculo oral para superar estos efectos tóxicos. Sin embargo, en los últimos tiempos un número de factores no solo han puesto en duda lo que se conocía acerca de la toxicidad de leucaena, sino que también han proporcionado nuevos conocimientos acerca de la distribución geográfica de $S$. jonesii. Estos factores incluyen encuestas sobre la situación de toxicidad a nivel mundial, una mejor comprensión de la química y el modo de acción de las toxinas, nuevas técnicas de secuenciación molecular y el cuestionamiento de la eficacia del inóculo in vitro. También existe confusión e ignorancia respecto a la ocurrencia e importancia de toxicidad en muchos países en todo el mundo. Las investigaciones en curso sobre la taxonomía y ecología del phylum Synergistetes y el desarrollo de mejores métodos de inoculación y de mejores soluciones de manejo, junto con actividades de extensión de sensibilización, desempeñarán un papel fundamental en el éxito futuro de los sistemas de alimentación ganadera a base de leucaena.

\section{Introduction}

Leucaena is a multipurpose forage tree legume widely used in the tropical world (Shelton and Brewbaker 1994)

Correspondence: Michael J. Halliday, School of Agriculture and Food Sciences, The University of Queensland, St Lucia, Qld 4072, Australia.

Email: m.halliday@uq.edu.au with estimates of up to 5 Mha planted worldwide (Brewbaker and Sorensson 1990). There are no current estimates but this area will have increased substantially (Dalzell et al. 2012). While first domesticated for human use 7000 years ago (Hughes 1998), its primary value is now as a feed for ruminants. Leucaena is high in crude protein (Jones 1979), highly palatable (Andrew et al. 2000), long-lived, and tolerant of frequent severe defoliation and drought. This latter feature is especially im- 
portant, as it provides edible forage long into the dry season (Shelton and Brewbaker 1994). Leucaena is a vitally important source of protein for ruminants throughout south-east Asia, China, India, Hawaii, the Pacific islands, Mexico, Central America, South America and Australia (Shelton and Brewbaker 1994). In tropical Australia, L. leucocephala ssp. glabrata cultivars were first released in the $1960 \mathrm{~s}$, and there are currently more than 200,000 ha of leucaena-grass pastures (Dalzell et al. 2012), with more plantings each year.

Factors such as the rapid increase in international demand for animal products, high cost of protein concentrates, and shortage of nitrogen for tropical grass pastures will increase the need for alternative high protein feed sources in the tropics. This is leading to increased plantings of leucaena globally. The eastern islands of Indonesia are just one of many examples, where leucaena is fulfilling an important role in ruminant production (Panjaitan 2012) and where its wider use is being promoted in Government programs.

However, while it has many positive nutritional benefits, leucaena possesses the toxic non-protein free amino acid mimosine in relatively high concentrations in leaves and young pods [up to $9 \%$ dry matter (DM) in young leaves and 4-7\% DM in seeds] (Hegarty et al. 1964b). Pioneering work on leucaena toxicity was conducted between 1976 and 1994 by R. J. Jones and colleagues, who published widely on the symptoms, chemistry, microbiology and management of toxicity (Hegarty et al. 1964b; Jones et al. 1976; Allison et al. 1992; Jones 1994). They found that mimosine was rapidly converted to 3,4-dihydroxypyridine (3,4-DHP) post-ingestion, resulting in reduced feed intake, decreased liveweight gain (LWG), and poor animal performance on otherwise high quality pasture (Jones and Hegarty 1984; Pattanaik et al. 2007). Jones and Hegarty (1984) reported that these symptoms occurred at intakes of leucaena $>30 \%$ of diet.

Research conducted in the 1980s led to the isolation and identification of a previously unknown, and at the time unusual species of bacterium from the rumen of a Hawaiian goat; it was shown to be a gram-negative obligatory anaerobic bacterium and was subsequently named Synergistes jonesii. Strains from this species of bacterium were introduced into Australian cattle herds in 1983 and provided protection against the toxic effects of leucaena by degrading DHP to harmless by-products (Jones and Megarrity 1986). This success was followed by the development of a commercial inoculum in Australia, comprised initially of rumen fluid (in vivo) and subsequently of fermenter-produced (in vitro) mixed inoculum containing $S$. jonesii (Klieve et al. 2002). Since animals were reported to readily transfer the 'bug' within a herd (Quirk et al. 1988; Pratchett et al. 1991) (the exact methods of which are unknown, but likely encapsulated in saliva or faeces), it was recommended that only $10 \%$ of the herd need be inoculated. Protection of herds from toxicity in this way has led to annual LWGs of up to $300 \mathrm{~kg}$ in inoculated beef cattle grazing leucaena-grass pastures in northern Australia (Wildin 1994).

For these reasons, the problem of leucaena toxicity was considered resolved in Australia; however, a survey of the protection status of herds in Queensland on high leucaena diets has shown that almost 50\% appeared to be unprotected, including previously inoculated herds (Dalzell et al. 2012). There was also poor understanding and awareness of leucaena toxicity by farmers, with ignorance of both methods of detection of toxicity and management to limit adverse effects. This was of great concern as undiagnosed subclinical toxicity leads to reduced animal production (Dalzell et al. 2012).

The aim of this paper is to clarify the many issues regarding leucaena toxicity and to update readers regarding recent findings and future directions.

\section{Occurrence of toxicity in tropical countries}

During 1984-94, a survey of leucaena toxicity status, based on assay of urinary DHP excretions, was conducted in many countries, where leucaena was being fed to ruminants, to determine the presence or absence of DHPdegrading bacteria (Jones 1994). R. J. Jones concluded that countries protected from toxicity by the presence of $S$. jonesii included: Indonesia, Vanuatu, Thailand, Malaysia, India, Seychelles, Mauritius and Mexico, while at least 13 other countries were not protected. He hypothesized that lack of protection in the latter countries may have caused an aversion to intensive feeding of leucaena and become a barrier to adoption, while countries protected from toxicity had a long history of use of leucaena as forage for ruminant production (Jones 1981; 1986).

However, detailed recent monitoring of ruminant leucaena toxicity has demonstrated a more complex situation. Using the criterion that mean urinary DHP levels in protected herds should be $<100 \mathrm{mg} / \mathrm{L}$ (Dalzell et al. 2012), a survey of 20 villages within 4 islands of eastern Indonesia found that village herds within close proximity $(<40 \mathrm{~km}$ and in some cases $<1 \mathrm{~km})$ differed in their protection status (Halliday et al. 2013b). It is therefore unwise to classify the protection status of whole countries. Furthermore, as leucaena feeding in the tropics increases, with movement of animals with DHP-degrading bacteria both into and out of villages where leucaena is fed, some ruminants may lose protection, while others in 
neighboring villages may gain protection, if their animals are maintained on leucaena.

Thailand's inclusion as a protected country (Jones 1994) was based on the absence of urinary DHP in a single goat farm in 1983. However, a comprehensive survey of goat farms within 4 Thai provinces in 2009 (Phaikaew et al. 2012) found that all 63 goats sampled had exceedingly high levels of urinary DHP, often $>1,000 \mathrm{mg} / \mathrm{L}$. Similarly, urine samples collected from goats consuming $100 \%$ leucaena in Mexico, also previously listed as a protected country, within the Yucatan region where leucaena is thought to have originated, had exceedingly high levels of DHP, in one case $>10,000$ $\mathrm{mg} / \mathrm{L}$ (Graham Kerven, unpublished data). Thus, it is not appropriate to refer to 'protected or unprotected' countries, as capability to degrade leucaena toxins varies among ruminants at the village and even farm level.

\section{Confusion regarding toxicity symptoms}

When leucaena was first introduced to Australia, the clinical symptoms of toxicity were quite serious, presenting as emaciated animals, with some animal mortalities (Jones et al. 1978). However, severe clinical symptoms are now rarely seen, and most farmers feeding leucaena are ignorant of the visible symptoms of toxicity. While some Australian graziers suspect subclinical toxicity by monitoring reductions in LWGs, livestock raisers in most other countries have no way of knowing if their animals are suffering from toxicity, as data are not available. Since their animals fed leucaena may still be performing better than those without legume, there is understandable confusion over the toxicity issue. Another highly anomalous situation is that many ruminants in the tropical world are consuming large amounts of leucaena for prolonged periods and excreting high concentrations of urinary DHP without any apparent clinical symptoms of toxicity (Phaikaew et al. 2012; Graham et al. 2013; Halliday et al. 2013b), including no indication of goiter (Palmer et al. 2010). The reasons for this are not understood, but may be due to chemical conjugation of the toxins, reducing their toxicity (mentioned later in this paper).

The symptoms associated with leucaena toxicity are now discussed and clarified. They are ascribed to both mimosine and its primary metabolites: 3,4-DHP and 2,3DHP (Figure 1). While structurally similar, these toxins have different modes of toxicity. Although there is some overlap, they are responsible for different clinical and subclinical symptoms. It is therefore essential that toxicity symptoms are understood and the causes correctly identified for proper management of leucaena-based feeding systems.

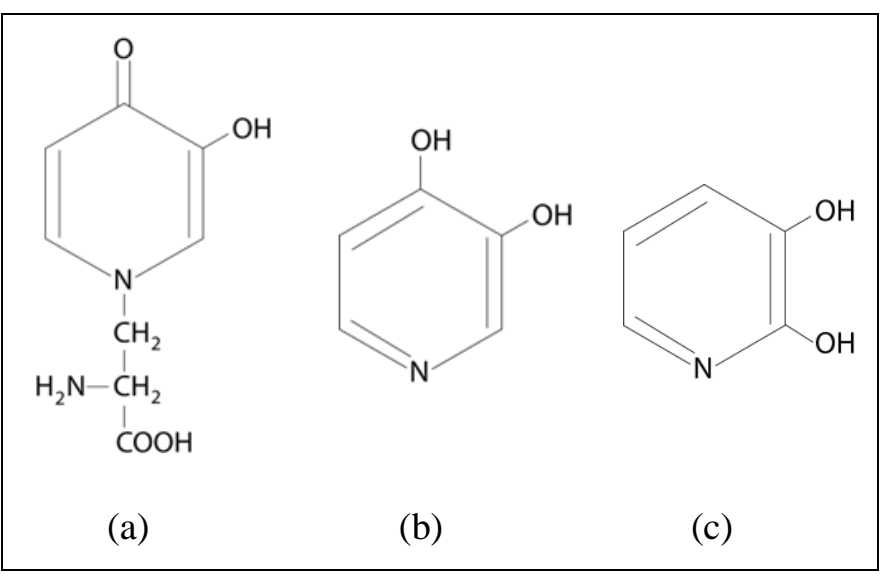

Figure 1. Mimosine (a) and its ruminal degradation products 3,4-DHP (b) and 2,3-DHP (c); adapted from Hammond (1995).

\section{Mimosine toxicity}

Mimosine $\quad[\beta-[N$-(3-hydroxy-4-oxopyridyl)]- $\alpha$-aminopropionic acid] (Hegarty et al. 1976) is acutely antimitotic, inhibiting the synthesis of DNA (Perry et al. 2005; Pandey and Dwivedi 2007), particularly in rapidly dividing cells (Tsai and Ling 1971; Jones and Hegarty 1984), and can cause damage to internal organs (Prasad and Paliwal 1989). The symptoms ascribed to mimosine include alopecia (Hegarty et al. 1964a; Ram et al. 1994), oesophageal lesions (Jones et al. 1978), foetal abortions (Holmes 1980), low bull fertility (Holmes 1981) and death (Jones et al. 1978; Prasad and Paliwal 1989; Dalzell et al. 2012). It should be noted that mimosine itself is not responsible for the symptoms of goiter (Hegarty et al. 1979).

Structurally, mimosine is a tyrosine analogue (Hegarty et al. 1964a; Hashiguchi and Takahashi 1977), capable of inhibiting enzyme functions such as tyrosine decarboxylase and tyrosinase (Crounse et al. 1962). The inhibition of these enzymes, especially of [3+]thymidine in the follicle bulbs of hair cells, along with the incorporation of mimosine into biologically vital proteins (Tsai and Ling 1971), can result in depilation of actively growing hairs.

For this reason, alopecia is one of the most commonly reported symptoms, when animals are first introduced to leucaena, and can occur within 7 days on $100 \%$ leucaena (Hegarty et al. 1964a). Hair loss is commonly observed from the penis sheath and tail areas, where growth is more continuous; mimosine affects the follicle bulb only in the active phase of growth (Hegarty et al. 1964a). This is best demonstrated in sheep as wool growth is largely continuous and therefore sensitive to alopecia from mimosine toxicity (Hegarty et al. 1964a). Alopecia is evident when levels of mimosine in diets are $>0.015 \%$ 
body weight (BW) (Szyszka and Termeulen 1985). As a diet of $100 \%$ fresh leucaena leaves may result in consumption of as high as $0.031 \%$ BW mimosine (Tangendjaja et al. 1985), it would seem that leucaena feeding at levels greater than $50 \%$ would lead to alopecia in unprotected animals.

While mimosine toxicity can be potentially severe, it is relatively short-term and appears only when animals are first introduced to high leucaena diets (Ghosh et al. 2007; O'Reagain 2009). Ruminants typically acquire the ability to fully degrade mimosine in high leucaena diets (>50\%) within 2 weeks from initial introduction (Ghosh et al. 2007); and excretion of mimosine ceases within 24 hours of removal of leucaena from the diet (O'Reagain 2009). For this reason, symptoms of mimosine toxicity rarely persist within an animal, especially if introduced to leucaena slowly (Jones 1979).

The degradation of mimosine to 3,4-dihydroxypyridine (3,4-DHP) occurs via many endogenous rumen bacteria (Hegarty et al. 1964a) and by plant hydrolase activity of endogenous enzymes within leaves (Smith and Fowden 1966; Lowry et al. 1983). Up to $30 \%$ of the mimosine is converted to 3,4-DHP in the initial process of mastication (Ram et al. 1994) within 1 hour of ingestion (Jones and Megarrity 1983). Although mimosine is readily degraded to 3,4-DHP, this does not result in detoxification.

Mimosine also forms strong complexes with metal ions (Hashiguchi and Takahashi 1977). While the chelation of mimosine antagonizes its antimitotic ability (Hashiguchi and Takahashi 1977), the process of chelation with high affinity metal ions from animal cells, such as $\mathrm{Fe}, \mathrm{Cu}$ and $\mathrm{Zn}$, inhibits many enzymatic pathways; these metals are also required for normal hair growth (Hegarty et al. 1964a; Hashiguchi and Takahashi 1977; Paul 2000). Ultimately, the chelatory effects of mimosine exacerbate the overall depilatory effects, resulting in overlap of some symptoms with DHP toxicity (Puchala et al. 1995).

\section{DHP toxicity}

The primary metabolite of mimosine is the compound 3-hydroxy-4(1H)-pyridine (3,4-DHP) (Hegarty et al. 1976), which, in the presence of certain ruminal microbes, can be further converted to its isomer 2,3dihydroxypyridine (2,3-DHP) (D'Mello 1992). DHP acts as a potent goitrogen, due to its antiperoxidase activity. By inhibiting essential peroxidase- and lactoperoxidasecatalyzed reactions (Christie et al. 1979; Lee et al. 1980), the iodination of tyrosine in the binding step of the thyroid is inhibited. This step is crucial for the synthesis of thyroid hormones, such as thyroxin $\left(\mathrm{T}_{4}\right)$ and triiodo- thyronine $\left(\mathrm{T}_{3}\right)$, resulting in depressed serum $\mathrm{T}_{4}$ levels, which causes overstimulation and enlargement (up to 4 times) of the thyroid glands (goiter) (Hegarty et al. 1979; Jones 1979; Megarrity and Jones 1983). Studies have also shown that persistent administrations of DHP increase the uptake of iodine in the hyperplastic thyroid, confirming the anti-thyroid effects of DHP (Hegarty et al. 1979). One effect of lowered serum $T_{4}$ and $T_{3}$ levels is reduced appetite, and ultimately a decreased LWG. Serum $\mathrm{T}_{4}$ levels below $13 \mathrm{nmol} / \mathrm{L}$ may even result in death (Jones et al. 1978).

Reduced iodine availability due to DHP can also affect the salivary glands. Iodine is incorporated into salivary glands via a different method and inhibits the trapping step rather than the binding step, as in the thyroid (Koutras et al. 1967; Harden et al. 1968), leading to excessive salivation after prolonged exposure to leucaena (Jones et al. 1976, 1978; Holmes 1981; Megarrity and Jones 1983; Ram et al. 1994).

Compounding the goitrogenic effects of DHP, is the fact that both isomers also strongly chelate with metal ions (Tsai and Ling 1971), forming complexes with $\mathrm{Zn}$, $\mathrm{Cu}$, and $\mathrm{Fe}$ in particular, leading to excretion and depletion of these minerals (Ghosh and Samiran 2007). A deficiency in $\mathrm{Zn}$ was shown to be responsible for skin lesions (Mills 1978; Paul 2000), increased salivation (Mills 1978; Puchala et al. 1996) and abnormal hair growth (Hashiguchi and Takahashi 1977). Zn deficiency can also be responsible for inhibiting DNA replication (Perry et al. 2005) and can adversely affect spermatogenesis (Yamaguchi et al. 2009). These all suggest that the chelation of essential minerals is a major toxic effect of DHP. The presence of existing deficiencies of essential minerals in the diet may hasten the manifestation of clinical toxicity symptoms.

The effects of DHP toxicity are a function of both amount of leucaena in the diet and time on leucaena. Clinical symptoms may take up to 8 weeks to become evident (Quirk et al. 1988). This can manifest itself in scenarios where new animals on a leucaena-grass paddock can gain up to $1 \mathrm{~kg} / \mathrm{hd} / \mathrm{d}$, while existing animals grazing that same paddock for longer periods can be gaining as little as $0-0.2 \mathrm{~kg} / \mathrm{hd} / \mathrm{d}$ (Jones and Bray 1983). These lowered LWGs were found to be directly related to lowered levels of serum $\mathrm{T}_{4}$, with a threshold of 25 $\mathrm{nmol} / \mathrm{L}$ before clinical symptoms such as drooling and hair loss were observed (Jones and Winter 1982). It is this chronic nature of DHP, the dual modes of toxicity, and the long periods when toxicity can go unnoticed that contribute to the complexity of recognition of potential toxicity.

However, as mentioned, inexplicably, goats in Thailand and Indonesia on long-term high leucaena diets 
were shown to be excreting high concentrations of 2,3DHP in urine without indication of goiter (Phaikaew et al. 2012; Halliday et al. 2013b).

\section{The dominance of 2,3-DHP}

The isomer 2,3-DHP was originally thought to be transitory, and indicative of incipient ruminal colonization of S. jonesii (Ford et al. 1984; Jones et al. 2009). Much recent data from Australia, Thailand and Indonesia contradict this notion of 2,3-DHP being transitory (Dalzell et al. 2012; Phaikaew et al. 2012; Graham et al. 2013; Halliday et al. 2013b) and indicate that it is usually the dominant isomer in ruminants fed leucaena long-term. Phaikaew et al. (2012) reported exceedingly high levels $(>1,000 \mathrm{mg} / \mathrm{L})$ of 2,3-DHP in the urine of ruminants fed over extended periods ( $>3$ months). It is generally considered that the isomers 3,4-DHP and 2,3-DHP are equally harmful (Lee et al. 1980; Ghosh et al. 2008). The latter has been shown to reduce intake (suppress appetite) (McSweeney et al. 1984), reduce milk production in dairy cows (Ghosh et al. 2007), and be fatal given intraruminally in pure form (Puchala et al. 1995).

In a controlled cattle feeding trial in India (Ghosh et al. 2007), 2,3-DHP was the dominant isomer 21 days after commencement of leucaena feeding in cattle naïve to $S$. jonesii, as was the case for animals offered 25$100 \%$ leucaena in a controlled trial in Queensland (Halliday et al. 2013a). In the latter trial, all steers on diets of 25-100\% leucaena were excreting 2,3-DHP at levels above $100 \mathrm{mg} / \mathrm{L}$ after only 2 weeks on leucaena, increasing through to week 7 , when it formed the majority of the DHP excreted.

The accumulation of high levels and proportions of 2,3-DHP in ruminants, both previously exposed to $S$. jonesii and those naïve to it, may suggest that: (a) rumen microbes other than $S$. jonesii are capable of degrading 3,4-DHP to 2,3-DHP; (b) the in vitro $S$. jonesii inoculum released in Australia may have lost/mutated the strains effective at complete DHP degradation; or (c) there are other environmental factors (including regulation of genes involved in DHP metabolism) affecting optimal ability of $S$. jonesii to completely degrade all DHP.

\section{Taxonomy and distribution of $S$. jonesii}

Recent advances in molecular techniques for the detection and sequencing of $S$. jonesii have allowed greater insights into the geographic spread and genetic variability of the bacterium. From the culture originally imported into Australia from a Hawaiian goat in 1982, 4 strains were later isolated, including the designated type-strain
78.1 (ATCC 49833) and 3 others (100-6, 113-4, 147-1) (Allison et al. 1992). The strains were shown to have differential specificity for degrading mimosine, and/or 3,4-DHP and 2,3-DHP (Jones 1994).

PCR amplification using $S$. jonesii specific primers of the $16 \mathrm{~S}$ rDNA (small sub-unit of the ribosome-ssRNA) was used as a molecular phylogenetic classifier, and has even identified $S$. jonesii $16 \mathrm{~S}$ rDNA sequences in the gut of disparate animals such as the horse, Tamar wallaby, baboon and the emu (Chris McSweeney, unpublished data). The theoretical limit of detection of $S$. jonesii by PCR is $10^{3}$ cells $/ \mathrm{mL}$; however, a realistic PCR amplification of genomic DNA from digesta is $10^{4}-10^{5}$ cells $/ \mathrm{mL}$ due to the co-precipitation of contaminating inhibitors. This problem was overcome by a second round of PCR (nested PCR) on the initial PCR products, which increased the sensitivity of detection to near theoretical limits. Sequencing of the amplified (nested) products not only confirmed the identity of $S$. jonesii but also detected mutations in that segment of the $16 \mathrm{~S}$ gene. These changes appeared as discrete mutations or 'single nucleotide polymorphisms' (SNPs) that may be correlated with their ability to degrade DHP, relative to the type strain. SNPs can be random or occur consistently at the same locus, termed 'hot-spots'.

A survey of animals consuming diets of $0-100 \%$ leucaena was conducted to understand the distribution and changes at the molecular level of $S$. jonesii (Chris McSweeney, unpublished data). Rumen fluid or faeces was collected from cattle in Queensland and from cattle, sheep, goats, buffalo and yak from Indonesia, Thailand, Vietnam, China and Brazil. In a number of these sites, animals were naïve to leucaena. In general, faecal samples failed to generate PCR products for $S$. jonesii $16 \mathrm{~S}$ rDNA from either Australian or international samples. The survey revealed that $S$. jonesii is far more widespread and indigenous to the rumen than originally realized and that many molecular variants of the type strain exist. The molecular detection of this bacterium internationally in ruminants, irrespective of their leucaena feeding status, corroborates some of the findings of Jones (1994), reporting on the inconsistent DHP-degrading capability of rumen fluid from animals from crosscontinental sites.

Yet, this information on its ubiquity has come with a proviso, that our sequence analysis from Australia and other countries showed SNPs, across $\sim 800$ of the 1500 bases of the $16 \mathrm{~S}$ gene of the bacterium. These SNPs were distributed primarily at 'hot-spots' in bases corresponding to $E$. coli nucleotide positions $268(\mathrm{C} \rightarrow \mathrm{T})$, $306(\mathrm{~A} \rightarrow \mathrm{G}), 328(\mathrm{G} \rightarrow \mathrm{A})$ and $870(\mathrm{~A} \rightarrow \mathrm{C})$ between bases 200-900 [ 700 base pairs (bp)] of the $S$. jonesii ATCC 
$16 \mathrm{~S}$ rDNA. All 4 SNPs were identified at varying frequencies in all farms surveyed in Queensland. Of these loci, '306' and ' 870 ' were almost always mutated when SNPs were detected. Surprisingly, these two SNPs were present consistently in the inoculum provided to the farmers. In about $50 \%$ of these sequences, all 4 SNPs were present.

In animals overseas, the very same SNPs were also distributed, ranging from frequencies of $15 \%$ (for ' 870 ' in Brazilian cattle) to $100 \%$ (all 4 SNPs in Vietnamese cattle and goats). Among all the international samples analyzed, those from Jinnan cattle, Tibetan yak and Indonesian buffalo were found to have S. jonesii, $100 \%$ identical to the type strain. Interestingly, the buffalo in Indonesia were on $100 \%$ leucaena for $0.5-1$ years and had high clearance of both 3,4-DHP and 2,3-DHP. The Jinnan cattle and Tibetan yak were naïve to leucaena. Other SNPs were detected, whose frequencies were not consistent across animals, geographical regions or loci.

It remains to be determined if these molecular changes also modify the ability of these strains to degrade DHP. A detailed molecular and physiologic analysis of these 'strains' is, thus, highly desirable in order to elucidate the link between genetic changes and DHP-degrading potential.

Attempts at molecular enumeration of $S$. jonesii from rumen digesta are similarly fraught with ambiguity, relating to the sensitivity and specificity of the quantitative real-time PCR (qPCR) technique. Compared with the 2-step nested PCR which produces $\sim 800$ bp long products, the qPCR typically uses a 100-200 bp PCR product for real-time amplification and analysis. Although this method has a statistically higher chance of amplifying a shorter target (100-200 bp) than the nested PCR (700-800 bp), it still has to overcome PCR inhibition and thus a lack or reduction of sensitivity, unlike the nested PCR. Any specific amplification, nevertheless, can accurately enumerate the target molecule (16S rDNA of $S$. jonesii) from a rumen sample. Several primer sets targeting the $S$. jonesii $16 \mathrm{~S}$ DNA, designed and tested during the past 4-5 years, have indicated $S$. jonesii exists in the rumen at very low numbers, even in animals foraging on leucaena and where degradation of DHP was apparently occurring (Graham et al. 2013).

This extensive molecular analysis of animals consuming leucaena demonstrates that $S$. jonesii is widespread with variants of the ATCC type strain. These variants may potentially be responsible for the partial DHP degradation results.

\section{Management of toxicity}

\section{Methods for detecting DHP toxicity}

A full understanding of DHP toxicity and of effective methods to detect subclinical toxicity is vital for productive management of animals on leucaena. There are several possible approaches to detection of toxicity, but the most effective method is assay of urine for DHP (Lowry et al. 1985; Phaikaew et al. 2012). Unmetabolized mimosine, 3,4-DHP and 2,3-DHP are readily absorbed into the blood stream and voided in the urine via glomerular filtration at the kidneys (Hammond 1995). While small amounts (up to 15\%) may be voided in the faeces (Hegarty et al. 1979; Jones and Hegarty 1984; Hammond 1995), most is readily absorbed from the gut and excreted via the kidneys (Lowry et al. 1985).

While HPLC analysis of urine (Dalzell et al. 2012) is currently the most accurate method of measuring DHP toxicity, sampling many animals for analysis by HPLC is too expensive for graziers, and prohibitive for farmers in developing countries. In response to the need for a rapid, accurate and inexpensive urine assay, a colorimetric test kit, modified from earlier work (Lowry et al. 1985), has been developed and refined as the most costeffective and immediate assessment of toxicity (Graham et al. 2013). This is now available to Australian graziers uncertain about the toxicity status of their herds. This improved urine test gives reliable, although not quantitatively precise, indications of the concentration and nature of the toxin.

DHP can be excreted in both the free form and as a conjugate with a glucose molecule. HPLC analysis with a reduced flow rate has been able to separate free DHP from conjugated DHP-glucoside. However, preservation of urine prior to analysis requires strong acidification, which hydrolyzes all conjugated DHP (Tangendjaja and Wills 1980), unless analysis is conducted immediately.

While assay of serum $\mathrm{T}_{4}$ and $\mathrm{T}_{3}$ can be used as an indicator of DHP toxicity (Jones et al. 1978; Megarrity and Jones 1983; Jones and Hegarty 1984; Ghosh et al. 2007), changes in thyroxin levels occur after longer-term exposure with considerable variation among animals (Michael Halliday, unpublished data). Likewise, the development of goiter in response to depressed thyroid hormones is also a cumulative longer-term effect. As noted, ruminants do not always develop enlarged thyroids on high leucaena diets. Accordingly, these methods are not a reliable indicator of current toxicity status. 


\section{Inoculation}

Following the initial discovery of $S$. jonesii, inoculation with rumen fluid collected from protected animals was the preferred method for transferring protection between herds, and even between countries (Jones et al. 1985). This seminal work on inoculation demonstrated that the capability to completely degrade DHP was transferred within 5 days following direct inoculation with rumen fluid (Jones and Lowry 1984; Jones and Megarrity 1986). In 1982, 10 cultures of rumen fluid from a single goat in Hawaii were imported to Australia and, in 1983, dosed into rumen-fistulated steers at the CSIRO Lansdown Research Station near Townsville (Jones and Megarrity 1986). Rumen fluid from these steers was then used as the source of inoculum, given via direct rumen injection, to $\sim 10 \%$ of the remaining herd at Lansdown, spreading passively to the entire herd. In 1984, strained rumen fluid from these cattle was administered to steers at the Queensland Government Brian Pastures Research Station near Gayndah (Quirk et al. 1988). It was from these 2 locations that rumen fluid was collected and distributed to Australian graziers and also to livestock raisers in both Ethiopia and China, with successful transfer of protection.

In 1995, production of the inoculum in an in vitro fermenter began, using rumen fluid containing the mixed bacterial inoculum sourced from cattle at Brian Pastures (Klieve et al. 2002). While originally successful in transferring protection, the efficacy of the current in vitro inoculum appears in doubt, as it is neither rapid nor completely successful in its degradation of DHP. It was thus postulated that the continually cultured oral inoculum may have lost some strains, and/or have undergone genetic modification and/or contained other strains with an altered DHP-degrading potential (Graham et al. 2013; Halliday et al. 2013a).

In Indonesia, animals identified as having $S$. jonesii by PCR analysis and confirmed by very low urinary DHP excretions, were selected as inoculum donors for direct rumen fluid transfer. To test the efficacy of transfer, animals known to be excreting high levels of DHP were inoculated with rumen fluid, which had been maintained in a strict anaerobic state at an appropriate temperature. However, the recipient goats continued excreting 2,3DHP at levels estimated at $>1,000 \mathrm{mg} / \mathrm{L}$ based on colorimetric assay 10 days after inoculation, indicating a lack of rapid successful response to inoculation. This occurred during August 2012 and was repeated in November 2012 with cattle and goats. Donors were established as high degraders of DHP and the presence of $S$. jonesii was confirmed by PCR analysis. Again, the ability to degrade DHP (or increased degradation) was not trans- ferred within 10 days. These recent findings (Michael Halliday, unpublished data) are in stark contrast with earlier work, where rumen fluid transfer resulted in complete degradation of DHP within 5 days in Indonesia (Jones and Lowry 1984) and within 3 days in Thailand (Palmer et al. 2010).They also raise questions regarding the ability of $S$. jonesii to be easily transferred, and therefore the capacity to degrade DHP.

\section{Other microbial control options}

Other microbial solutions apart from $S$. jonesii have been investigated as alternative biological control methods. Domínguez-Bello and Stewart (1991) reported the isolation of a DHP-degrading Clostridium bacterium, which was subsequently lost. In China, 4 strains were isolated, which together were able to degrade up to $60 \%$ of DHP in vitro within 3 days. These gram-positive facultative and obligate anaerobes were identified as Lactobacillus spp., Streptococcus bovis and Clostridium sporogenes (Tan et al. 1994) and were quite different from $S$. jonesii. Strains of obligate aerobic Streptococci, capable of degrading DHP, were reported by Chhabra et al. (1998). Researchers in Germany isolated a mimosine- (and DHP-) degrading bacterium from the rumen fluid of steers naïve to leucaena (Aung et al. 2011). After continuous culture with mimosine for 16 days, their work reported an aero-tolerant gram-negative coccobacillus was isolated, belonging to the genus Klebsiella. While capable of growing under anaerobic conditions, it grew best in aerobic conditions. As such, it may not readily persist in high numbers in the anaerobic conditions of the rumen. The researchers also described a method for stabilizing the inoculum in alginate beads, increasing its shelf-life at room temperature by up to 8 weeks. Methods such as this, and freeze-drying, may be incorporated into the production in vitro of $S$. jonesii inoculum in the future, preventing loss of bacterial numbers in transit. However, further research is required.

\section{Supplementation and conjugation}

As mentioned, one of the major toxic effects of DHP is to strongly chelate essential minerals such as $\mathrm{Fe}$ and $\mathrm{Zn}$ (Stunzi et al. 1980). Methods for increasing conjugation and/or chelation of DHP by modifying the diet have been postulated as a way to reduce the toxic effects of leucaena.

While Christie et al. (1979) reported DHP conjugated with a glucose molecule to have reduced antiperoxidase activity in vitro, Hegarty et al. (1979) showed that the conjugate was of the same order of chronic goitrogenicity in vivo. However, chelation and conjugation in- 
crease the polarity of DHP, resulting in a more watersoluble molecule, which can be voided more efficiently. In addition, by attaching a sugar molecule or metal ion at the active binding hydroxyl site, its toxic chelating ability is reduced (Lowry et al. 1985). There is other evidence that the toxic effects of DHP are reduced due to conjugation; recent tests on highly productive animals consuming high leucaena diets in eastern Indonesia showed that they were excreting high levels (estimated at $>1,000 \mathrm{mg} / \mathrm{L}$ using colorimetric analysis) of conjugated DHP (Michael Halliday, unpublished data). These animals may have developed a coping mechanism of being able to conjugate DHP, without ruminal degradation, thus reducing its toxicity. This may explain the absence of symptoms.

While DHP can be excreted in the free form, it is normal for up to $33 \%$ to be found conjugated as a glucuronide in urine (Hegarty et al. 1964a; 1976). Supplementation with molasses has previously been shown to increase both the conjugation of DHP, and the amount being excreted in unprotected animals (Elliott et al. 1985). Animals receiving a high molasses supplement did not exhibit a decline in $\mathrm{T}_{4}$ levels. However, the level of molasses required to achieve this effect was $\sim 40 \%$ dry matter intake, making it an impractically large component of the diet.

Supplementation with minerals to chelate mimosine and DHP has been suggested as a method of detoxification (Hashiguchi and Takahashi 1977). Supplemental mineral ions were shown to have prevented hair loss and skin lesions (Jones et al. 1978), doubled excretion of intra-ruminally infused 2,3-DHP, lowered the levels of 2,3-DHP in the rumen and plasma, and prevented clinical toxicity symptoms from developing (Puchala et al. 1995), suggesting that kidney clearance of DHP is more efficient when chelated or conjugated (Puchala et al. 1995). While DHP is more efficiently voided in the chelated form, if essential metal ions are not replaced, deficiencies in these elements will result in toxicity symptoms (Puchala et al. 1996).

\section{Feeding management}

Management strategies that control exposure to leucaena have been effective in limiting the extent of toxicity. Prior to the discovery of $S$. jonesii, Jones and Hegarty (1984) suggested that leucaena should not exceed $30 \%$ of the diet. As mimosine toxicity rarely occurs in animals regularly consuming leucaena and since DHP toxicity is a factor of both time on leucaena and amount of leucaena in the diet (Hammond 1995), moderate levels of leucaena in the diet for short periods ( $\leq 2-3$ months) can limit the toxic effects. Quirk et al. (1988) showed that it can take up to 8 weeks for clinical symptoms to become evident. Alternating time on leucaena with time on other feed sources can reduce the toxic effects associated with DHP. However, reducing consumption of leucaena limits the LWG potential of a fattening system. Given that leucaena is often one of the only feedstuffs available during the extended dry season in many tropical smallholder feeding systems, an effective biological control mechanism is the most practical solution to leucaena toxicity.

An example of limiting exposure is found in fattening systems in Sumbawa, eastern Indonesia, many of which feed high levels of leucaena to Bali bulls (up to $100 \%$ of the diet), and typically fatten over a 4-6-month period (Panjaitan et al. 2013). Farmers report that initial hair loss is common (probably due to mimosine toxicity), followed by complete recovery. They also report that an initial aversion of naïve animals to high leucaena diets can be overcome by using a mixture of fresh faeces from an older bull and fresh leucaena leaves as a source of 'inoculum' (Panjaitan et al. 2013).

Other less effective management strategies include drying leucaena. While this converts most of the mimosine to DHP (Hegarty et al. 1964b; Wee and Wang 1987), it does not overcome the toxic effects of DHP itself.

\section{Future research, development and extension directions}

Leucaena toxicity, as indicated by high levels of urinary DHP, is still common through tropical countries, where leucaena is fed to ruminants.

Farmers and Government agencies promoting the use of leucaena are often ignorant of the effects of leucaena toxicity, especially since there are usually no clinical symptoms. It is vital that research and education are continued to improve understanding and management of this extremely productive legume, in order to optimize animal production and eliminate negative impacts on animal health.

Bacterial control offers the most beneficial and practical solution, provided easy transfer mechanisms are developed, and long-term persistence of efficacy of DHP degradation can be assured. Future research goals include: (a) improved molecular methods for the identification and understanding of the functionality of $S$. jonesii and the Synergistetes phylum; (b) alternative microbial control options; (c) improved inoculation protocols within Australia and developing countries; and (d) alternative methods of detoxifying DHP. 


\section{Acknowledgments}

The following are acknowledged for their contributions: Dr Tanda Panjaitan, Dr Dahlanuddin, Dr Jacob Nulik and Debora Kana Hau for experimental support in Indonesia; ACIAR for supporting Indonesian field researchers to provide physical assistance with collection of rumen fluid and urine samples; and Dr Scott Dalzell and Hayley Giles for their guidance. The work was done with the financial support of ACIAR.

\section{References}

Allison MJ; Mayberry,WR; McSweeney CS; Stahl DA. 1992. Synergistes jonesii, gen. nov., sp. nov.: a rumen bacterium that degrades toxic pyridinediols. Systematic and Applied Microbiology 15:522-529.

Andrew WM; Williams MJ; Allison MJ; Chase CC; Chambliss CG; Kalmbacher RS; Kunkle, WE. 2000. Detection of Synergistes jonesii in cattle and sheep feces. In: Phillips MJ, ed. American Forage and Grassland Council Proceedings Vol. 9:165168.

Aung A; ter Meulen U; Gessler F; Böhnel H. 2011. Isolation of Mimosine Degrading Bacteria from Rumen Juice and Mass Production by Göttingen Bioreactor Technology. Journal of Agricultural Science and Technology A 1: 764-772.

Brewbaker JL; Sorensson CT. 1990. New tree crops from interspecific leucaena hybrids. In: Janick J; Simon JE, eds. Advances in new crops. Timber Press, Portland, OR, USA. p. 283-289.

Chhabra A; Kaur J; Malik RK; Kaur H. 1998. Isolation and characterization of ruminal bacteria degrading DHP, the toxic metabolite of mimosine. Indian Journal of Animal Sciences 68:1270-1273.

Christie GS; Lee CP; Hegarty MP. 1979. Antithyroid properties of 3-hydroxy-4(1H)-pyridone: Antiperoxidase activity and effect on thyroid function. Endocrinology 105:342-347.

Crounse RG; Maxwell JD; Blank H. 1962. Inhibition of growth of hair by mimosine. Nature 194:694-695.

D'Mello JPF. 1992. Chemical constraints to the use of tropical legumes in animal nutrition. Animal Feed Science and Technology 38:237-261.

Dalzell SA; Burnett DJ; Dowsett JE; Forbes VE; Shelton HM. 2012. Prevalence of mimosine and DHP toxicity in cattle grazing Leucaena leucocephala pastures in Queensland, Australia. Animal Production Science 52:365-372.

Domínguez-Bello MG; Stewart CS. 1991. Characteristics of a rumen clostridium capable of degrading mimosine, 3(Oh)4-(1h)-pyridone and 2,3-dihydroxypyridine. Systematic and Applied Microbiology 14: 67-71.

Elliott R; Norton BW; Milton JTB; Ford CW. 1985. Effects of molasses on mimosine metabolism in goats fed fresh and dried leucaena with barley straw. Australian Journal of Agricultural Research 36:867-875.
Ford CW; Megarrity RG; Meehan GV. 1984. 2,3-DHP, a novel mimosine metabolite. Leucaena Research Reports $5: 2$

Ghosh MK; Samiran B. 2007. Mimosine toxicity - a problem of Leucaena feeding in ruminants. Asian Journal of Animal and Veterinary Advances 2:63-73.

Ghosh MK; Atreja PP; Buragohain R; Bandyopadhyay S. 2007. Influence of short-term Leucaena leucocephala feeding on milk yield and its composition, thyroid hormones, enzyme activity, and secretion of mimosine and its metabolites in milk of cattle. Journal of Agricultural Science 145:407-414.

Ghosh MK; Atreja P; Bandyopadhyay S. 2008. Effect of Leucaena leaf meal feeding in Karan Fries crossbred calves. Indian Veterinary Journal 85:44-46.

Graham SR; Dalzell SA; Nguyen TN; Davis CK; Greenway D; McSweeney CS; Shelton HM. 2013. Efficacy, persistence and presence of Synergistes jonesii inoculum in cattle grazing leucaena in Queensland: On-farm observations pre- and post-inoculation. Animal Production Science 53 (in press).

Halliday MJ; Giles HE; Dalzell SA; McSweeney CS; Shelton HM. 2013a. The efficacy of in vitro Synergistes jonesii inoculum to prevent DHP toxicity in steers fed different leucaena/grass diets. Proceedings of the 22nd International Grassland Congress, Sydney, Australia, 15-19 September 2013 (in press).

Halliday MJ; Panjaitan T; Nulik J; Dahlanuddin; Padmanabha J; McSweeney CS; Shelton HM. 2013b. Prevalence of DHP toxicity and detection of $S$. jonesii in ruminants consuming Leucaena leucocephala in eastern Indonesia. Proceedings of the 22nd International Grassland Congress, Sydney, Australia, 15-19 September 2013 (in press).

Hammond AC. 1995. Leucaena toxicosis and its control in ruminants. Journal of Animal Science 73:1487-1492.

Harden RM; Alexande WD; Chisholm CJ; Shimmins J. 1968. Salivary iodine trap in nontoxic goiter. Journal of Clinical Endocrinology \& Metabolism 28:117-120.

Hashiguchi H; Takahashi H. 1977. Toxicity of L-mimosine and its chelate forming nature with metal ions. Kumamoto Medical Journal 30:101-110.

Hegarty MP; Court RD; Schinckel PG. 1964a. Reaction of sheep to the consumption of Leucaena glauca Benth. and to its toxic principle mimosine. Australian Journal of Agricultural Research 15:153-167.

Hegarty MP; Court RD; Thorne PM. 1964b. The determination of mimosine and 3,4-dihydroxypyridine in biological material. Australian Journal of Agricultural Research 15:168-179.

Hegarty MP; Court RD; Christie GS; Lee CP. 1976. Mimosine in Leucaena leucocephala is metabolized to a goitrogen in ruminants. Australian Veterinary Journal 52:490.

Hegarty MP; Lee CP; Christie GS; Court RD; Haydock KP. 1979. The goitrogen 3-hydroxy-4(1h)-pyridone, a ruminal metabolite from Leucaena leucocephala - effects in mice and rats. Australian Journal of Biological Sciences 32: 27-40. 
Holmes JHG. 1980. Toxicity of Leucaena leucocephala. II. Reduced fertility of heifers grazing Leucaena leucocephala. Papua New Guinea Agricultural Journal 31: 47-50.

Holmes JHG. 1981. Toxicity of Leucaena leucocephala for steers in the wet tropics. Tropical Animal Health and Production 13:94-100.

Hughes C. 1998. Monograph of Leucaena (LeguminosaeMimosoideae). Systematic Botany Monographs Vol. 55.

Jones RJ. 1979. The value of Leucaena leucocephala as a feed for ruminants in the tropics. World Animal Review $31: 13-23$.

Jones RJ. 1981. Does ruminal metabolism of mimosine explain the absence of Leucaena toxicity in Hawaii? Australian Veterinary Journal 57:55-56.

Jones RJ. 1986. Leucaena - International experience. Tropical Grasslands 20:83-85.

Jones RJ. 1994. Management of anti-nutritive factors - with special reference to leucaena. In: Gutteridge RC; Shelton HM, eds. Forage Tree Legumes in Tropical Agriculture. CABI, Wallingford, UK. p. 216-231.

Jones RJ; Blunt CG; Holmes JHG. 1976. Enlarged thyroid glands in cattle grazing leucaena pastures. Tropical Grasslands 10:113-116.

Jones RJ; Blunt CG; Nurnberg BI. 1978. Toxicity of Leucaena leucocephala - effect of iodine and mineral supplements on penned steers fed a sole diet of leucaena. Australian Veterinary Journal 54:387-392.

Jones RJ; Winter WH. 1982. Serum thyroxine levels and liveweight gain of steers grazing leucaena pastures. Leucaena Research Reports 3:2.

Jones RJ; Bray RA. 1983. Agronomic Research in the Development of Leucaena as a Pasture Legume in Australia. In: Leucaena Research in the Asian-Pacific Region. Proceedings of a workshop held in Singapore, November 1982. p. 41-49.

Jones RJ; Megarrity RG. 1983. Comparative toxicity responses of goats fed on Leucaena leucocephala in Australia and Hawaii. Australian Journal of Agricultural Research 34:781-790.

Jones RJ; Hegarty MP. 1984. The effect of different proportions of Leucaena leucocephala in the diet of cattle on growth, feed-intake, thyroid-function and urinaryexcretion of 3-hydroxy-4(1h)-pyridone. Australian Journal of Agricultural Research 35:317-325.

Jones RJ; Lowry JB. 1984. Australian goats detoxify the goitrogen 3-hydroxy-4(1H) pyridone (DHP) after rumen infusion from an Indonesian goat. Experientia 40:1435-1436.

Jones RJ; Lowry JB; Megarrity RG. 1985. Transfer of DHPdegrading bacteria from adapted to unadapted ruminants. Leucaena Research Reports 6:5-6.

Jones RJ; Megarrity RG. 1986. Successful transfer of DHPdegrading bacteria from Hawaiian goats to Australian ruminants to overcome the toxicity of Leucaena. Australian Veterinary Journal 63:259-262.
Jones RJ; Coates DB; Palmer B. 2009. Survival of the rumen bacterium Synergistes jonesii in a herd of Droughtmaster cattle in north Queensland. Animal Production Science 49:643-645.

Klieve AV; Ouwerkerk D; Turner A; Roberton R. 2002. The production and storage of a fermentor-grown bacterial culture containing Synergistes jonesii, for protecting cattle against mimosine and 3-hydroxy-4 $(1 \mathrm{H})$-pyridone toxicity from feeding on Leucaena leucocephala. Australian Journal of Agricultural Research 53:1-5.

Koutras DA; Tassopoulos CN; Marketos S. 1967. Endemic Goiter in Greece: Salivary Iodide Clearance in Goitrous and Nongoitrous Persons. Journal of Clinical Endocrinology \& Metabolism 27:783-788.

Lee CP; Christie GS; Hegarty MP. 1980. Anti-thyroid and anti-perioxidase activity of some isomeric dihydroxy pyrodines. Thyroid Research III, Proceedings of the 8th International Thyroid Congress, Sydney 1980. p. 137.

Lowry JB; Tangendjaja M; Tangendjaja B. 1983. Autolysis of mimosine to 3-hydroxy-4-1(H)pyridine in green tissues of Leucaena leucocephala. Journal of the Science of Food and Agriculture 34:529-533.

Lowry JB; Tangendjaja B; Cook NW. 1985. Measurement of mimosine and its metabolites in biological materials. Journal of the Science of Food and Agriculture 36:799-807.

McSweeney CS; Bamualim A; Murray RM. 1984. Ruminal motility in sheep intoxicated with 2,3-dihydroxypyridine. Australian Veterinary Journal 61:271-272.

Megarrity RG; Jones RJ. 1983. Toxicity of Leucaena leucocephala in ruminants - the effect of supplemental thyroxine on goats fed on a sole diet of leucaena. Australian Journal of Agricultural Research 34:791-798.

Mills CF. 1978. Zinc in ruminant nutrition. Annual Report of Studies in Animal Nutrition and Allied Sciences 34:105-115.

O'Reagain JH. 2009. Rates of Urinary Toxin Excretion in Unprotected Steers Fed Leucaena leucocephala. Unpublished Thesis. The University of Queensland, Brisbane, Australia.

Palmer B; Jones RJ; Poathong S; Chobtang J. 2010. Withincountry variation in the ability of ruminants to degrade DHP following the ingestion of Leucaena leucocephala a Thailand experience. Tropical Animal Health and Production 42:161-164.

Pandey AK; Dwivedi UN. 2007. Induction, isolation and purification of mimosine degradation enzyme from newly isolated Pseudomonas putida STM 905. Enzyme and Microbial Technology 40:1059-1066.

Panjaitan T. 2012. Performance of male Bali cattle in village system of Lombok. Paper presented at 15th AAAP Animal Science Congress, Bangkok, Thailand, 26-30 November 2012.

Panjaitan T; Fauzan M; Dahlanuddin; Halliday MJ; Shelton HM. 2013. Growth of Bali bulls fattened with forage tree legumes in Eastern Indonesia: Leucaena leucocephala in Sumbawa. In: Proceedings of the 22nd International 
Grassland Congress, Sydney, Australia, 15-19 September 2013 (in press).

Pattanaik AK; Khan SA; Goswami TK. 2007. Influence of iodine on nutritional, metabolic and immunological response of goats fed Leucaena leucocephala leaf meal diet. Journal of Agricultural Science 145:395-405.

Paul SS. 2000. Detoxification of mimosine and dihydroxypyridone: a review. Agricultural Reviews 21:104-109.

Perry C; Sastry R; Nasrallah IM; Stover PJ. 2005. Mimosine attenuates serine hydroxymethyltransferase transcription by chelating zinc - Implications for inhibition of DNA replication. Journal of Biological Chemistry 280:396-400.

Phaikaew C; Suksaran W; Ted-Arsen J; Nakamanee G; Saichuer A; Seejundee S; Kotprom N; Shelton HM. 2012. Incidence of subclinical toxicity in goats and dairy cows consuming leucaena (Leucaena leucocephala) in Thailand. Animal Production Science 52:283-286.

Prasad J; Paliwal OP. 1989. Pathological changes in experimentally induced leucaena toxicity in lambs. Indian Veterinary Journal 66:711-714.

Pratchett D; Jones RJ; Syrch FX. 1991. Use of DHP-degrading rumen bacteria to overcome toxicity in cattle grazing irrigated leucaena pasture. Tropical Grasslands 25: 268-274.

Puchala R; Sahlu T; Davis JJ; Hart SP. 1995. Influence of mineral supplementation on 2,3-dihydroxypyridine toxicity in Angora goats. Animal Feed Science and Technology 55:253-262.

Puchala R; Pierzynowski SG; Sahlu T; Hart SP. 1996. Effects of mimosine administered to a perfused area of skin in Angora goats. British Journal of Nutrition 75:69-79.

Quirk MF; Bushell JJ; Jones RJ; Megarrity RG; Butler KL. 1988. Live-weight gains on leucaena and native grass pastures after dosing cattle with rumen bacteria capable of degrading DHP, a ruminal metabolite from leucaena. Journal of Agricultural Science, Cambridge 111:165-170.

Ram JJ; Atreja PP; Chopra RC; Chhabra A. 1994. Mimosine degradation in calves fed a sole diet of Leucaena leucocephala in India. Tropical Animal Health and Production 26:199-206.

Shelton HM; Brewbaker JL. 1994. Leucaena leucocephala the most widely used forage tree legume. In: Gutteridge
RC; Shelton HM, eds. Forage Tree Legumes in Tropical Agriculture. CAB International, Wallingford, UK.

Smith IK; Fowden L. 1966. A study of mimosine toxicity in plants. Journal of Experimental Botany 17:750-761.

Stunzi H; Harris RLN; Perrin DD; Teitei T. 1980. Stability constants for metal complexation by isomers of mimosine and related compounds. Australian Journal of Chemistry 33:2207-2220.

Szyszka M; Termeulen U. 1985. The reaction of sheep to the consumption of the toxic mimosine in Leucaena leucocephala. Zeitschrift für Tierphysiologie, Tierernährung und Futtermittelkunde - Journal of Animal Physiology and Animal Nutrition 53:65-69.

Tan P; Wang X; Wang J. 1994. Rumen bacteria degrading toxic mimosine and dihydroxypyridine compounds in China. Wei Sheng Wu Xue Bao 34:379-384.

Tangendjaja B; Wills RBH. 1980. Analysis of mimosine and 3-hydroxy-4(1H)-pyridone by high-performance liquid chromatography. Journal of Chromatography 202: 317-318.

Tangendjaja B; Lowry JB; Wills RB. 1985. Degradation of mimosine and 3-hydroxy-4(IH)-pyridone (DHP) by Indonesian goats. Tropical Animal Production 10:39-43.

Tsai WC; Ling KH. 1971. Toxic action of mimosine -1 . Inhibition of mitosis and DNA synthesis of H.Ep-2 cell by mimosine and 3,4-dihydroxypyridine. Toxicon 9:241-247.

Wee KL; Wang SS. 1987. Effect of post-harvest treatment on the degradation of mimosine in Leucaena leucocephala leaves. Journal of the Science of Food and Agriculture 39:195-201.

Wildin JH. 1994. Beef production from broadacre leucaena in central Queensland. In: Gutteridge RC; Shelton HM, eds. Forage Tree Legumes in Tropical Agriculture. CAB International, Wallingford, UK.

Yamaguchi S; Miura C; Kikuchi K; Celino FT; Agusa T; Tanabe S; Miura T. 2009. Zinc is an essential trace element for spermatogenesis. Proceedings of the National Academy of Sciences of the United States of America 106:10859-10864.

Tropical Grasslands-Forrajes Tropicales is an open-access journal published by Centro Internacional de Agricultura Tropical (CIAT). This work is licensed under a Creative Commons Attribution-NonCommercial-ShareAlike 3.0 Unported License. To view a copy of this license, visit http://creativecommons.org/licenses/by-nc-sa/3.0/ 
Halliday MJ; Padmanabha J; McSweeney CS; Kerven G; Shelton HM. 2013. Leucaena toxicity: a new perspective on the most widely used forage tree legume. Tropical Grasslands - Forrajes Tropicales 1:1-11.

DOI: $10.17138 /$ TGFT(1)1-11

This paper was presented at the $22^{\text {nd }}$ International Grassland Congress, Sydney, Australia, 15-19 September 2013. Its publication in Tropical Grasslands - Forrajes Tropicales is the result of a co-publication agreement with the IGC 2013 Organizing Committee. Except for adjustments to the journal's style and format, the text is essentially the same as that published in: Michalk LD; Millar GD; Badgery WB; Broadfoot KM, eds. 2013. Revitalising Grasslands to Sustain our Communities. Proceedings of the $\mathbf{2 2}^{\text {nd }}$ International Grassland Congress, Sydney, Australia, 2013. New South Wales Department of Primary Industries, Orange, NSW, Australia. p. $179-187$. 